\title{
Effect Of Organic And Inorganic Fertilizers On Okra (Abelmoschus esculentus L. Moench) Production And Incidence Of Insect Pests In The Humid Tropics
}

\author{
Sylvester R. Atijegbe ${ }^{1}$, Babatunde O. Nuga, Ndowa E. S. Lale, and Ruth N. \\ Osayi \\ Department of Crop and Soil Science, Faculty of Agriculture. University of Port Harcourt, Rivers State. Nigeria
}

\begin{abstract}
A field experiment was conducted at the University of Port Harcourt Teaching and Research Farm, Choba, Nigeria to compare the effects of NPK 15: 15: 15 and poultry manure on the yield of okra and incidence of insect pests on the crop. Performance of okra (Abelmoschus esculentus L. Moench) was assessed using inorganic and organic fertilizer. The treatments were fitted in a Randomized Complete Block Design (RCBD) replicated thrice. Application of poultry manure $(P M)$ at the rate of 10 tha- $^{1}$ had the highest yield and reduced number of insect pests, although mean plant height and mean leaf number were highest with $500 \mathrm{kgha-}{ }^{1} \mathrm{NPK}$ treatment at $10 \mathrm{WAP}$, mean leaf number followed a similar pattern. Stem girth was highest in 10tha- ${ }^{1}$ poultry manure and was not significantly different from 500kgha- ${ }^{1}$ NPK treatment. Complementary application of 10tha- ${ }^{1}$ poultry manure and 300kgha- ${ }^{1}$ NPK favoured okra growth and yield most in terms of quantity and quality (market value) and decreased insect pest infestations. Poultry manure at 10tha- ${ }^{1}$ turned out to be the most beneficial application compared with the other treatments.
\end{abstract}

Key Words: Okra, PM, NPK, insect pests, infestation.

\section{Introduction}

Okra, Abelmoschus esculentus L. Moench is a popular vegetable in tropical and sub-tropical countries of the world grown for its pod (Folorunso and Ojeniyi, 2003). It is a member of the hibiscus family, Malvaceae and has the typical floral characteristics of that family. Originating from Africa, it is now widely distributed in the tropics including Nigeria (National Research Council, 2006). It is an important vegetable crop occupying a land area of 277,000 hectares with a production of 731,000 metric tons worldwide and productivity of 2.63 tha- ${ }^{1}$ in Nigeria (FAO, 2006).

Okra is valued for its edible green pods (fruits), a capsule that contains many seeds. However, its leaves are also eaten as a vegetable. Okra seeds are used as a non-caffeinated substitute for coffee and also as a source of seed oil (FAO, 2006). Okra is said to be of economic importance because of its nutritional value that has the potential to improve food security (FAO, 2006).

The use of organic amendments applied to soil not only enhances its nutrient status but also reduces the incidence of pest (Adilakshi et al., 2007). Improvement of soil fertility through the application of fertilizers has become an essential factor that enables the world to feed billions of people of its population (Brady and Weil, 1999). Soil fertility is usually maintained by the application of organic and inorganic fertilizers (Okigbo, 1985), and there is also an improvement in the physical and biological properties of the soils (Okwuagwu et al., 2003). The use of inorganic fertilizers can improve crop yields, soil pH, total nutrient content and nutrient availability (Akande et al., 2010); most especially in the tropics where soils are adversely affected by suboptimal soil fertility and erosion causing deterioration of the nutrient status and changes in population of soil organisms (Economic Commission for Africa, 2001). But its use is constrained by acidity, scarcity, nutrient imbalance and it is no longer within the reach of poor-resource farmers due to its high cost. When excessively used, it also has a depressing effect on yield. This causes a reduction in number of fruits, delays and reduces fruit setting (John et al., 2004).

The use of organic manures as a means of maintaining and increasing soil fertility has been advocated (Alasiri and Ogunkeye, 1999). Some of these materials have also been found to control pathogens (Muhammed et al., 2001). Animal manures, when efficiently and effectively used, ensure sustainable crop productivity by immobilizing nutrients that are susceptible to leaching. Nutrients contained in manures are released more slowly and are stored for a longer time in the soil thus ensuring longer residual effects; improve root development and higher crop yields (Sharma and Mittra, 1991; Abou-Magel et al., 2006).

Poultry manure's relative resistance to microbial degradation is essential for establishing and maintaining optimum soil physical condition and is important for plant growth. It is also very cheap and effective as a good source of nitrogen for sustainable crop production (Dauda et al., 2008). Surekha and Rao (2001) and Prakash et al., (2002) had earlier explored the use of organic manures for managing the pests of 
okra. This research investigated the effect of poultry manure and inorganic fertilizer on the yield of okra and incidence of insect pests in the humid tropical ecological zone of Nigeria.

\subsection{Study site}

\section{Materials And Method}

The study was conducted at the Teaching and Research Farm, Faculty of Agriculture, University of Port Harcourt, Rivers State, Nigeria. The study area falls within the rainforest zone of the South-South Nigeria and is located on latitude $04^{\circ} 54 \mathrm{~N}$ and longitude $06^{\circ} 55 \mathrm{E}$, with a mean temperature of $27^{\circ} \mathrm{C}$, relative humidity of $78 \%$ and rainfall of between $2500-4000 \mathrm{~mm}$ per annum. The study was conducted during the early rainy season from April to June 2011.

\subsection{Soil and PM analysis}

Soil samples were taken at a depth of $0-15 \mathrm{~cm}$ before and after the study and analyzed. Samples of poultry manure (PM) were also collected and analyzed according to standard protocol (AOAC, 1990).

\subsection{Experimental design}

The experiment was laid out in a Randomized Complete Block Design (RCBD). The total number of plots was 21. The plot dimension was $2 \mathrm{~m} \times 1.1 \mathrm{~m}=2.2 \mathrm{~m}^{2}$. Seven treatments and three replicates were applied: untreated,

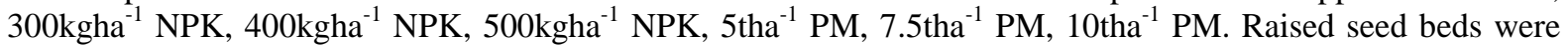
well prepared by ploughing and harrowing. PM was applied and incorporated based on treatments two weeks before sowing, while NPK fertilizer was applied as a single dose two weeks after emergence by the band application.

\subsection{Source of materials}

A local seed variety obtained from Wurukpu market in Obelle town, Emohua L.G.A. of Rivers State was used. PM was sourced from a commercial deep litter farm in Ohwepa, Choba, Obio/Akpor Local Government Area (L.G.A.) of Rivers State and NPK (15:15:15) was obtained from the fertilizers unit of the Rivers State Agricultural Development Programme (ADP) at Rumuokoro, Obio/Akpor L.G.A. of Rivers State.

Weeding was done manually by hoe and hand pulling until the vines spread, covered the plots and were able to suppress weeds.

\subsection{Data collection}

\subsubsection{Plant parameters}

Parameters including plant height, stem girth, number of leaves, fruit length, fruit diameter and fruit weight were recorded.

\subsubsection{Insect parameters}

Insects were collected and recorded during morning hours (6.00 and 7.00am), preserved in 75\% ethanol and samples were then sent to the Insect Museum of the Ahmadu Bello University Zaria, Kaduna State, Nigeria for identification.

\subsubsection{Data analysis}

All data collected were subjected to analysis of variance (ANOVA) using Statistics for Agricultural Scientist (SAS) package and treatment means were separated by least significant difference (LSD) at 5\% level of probability.

\subsection{Soil physical and chemical properties before and after cropping and PM Analysis}

The soil before treatment was $812 \mathrm{gkg}^{1}{ }^{1}$ sand, $87 \mathrm{gkg}^{-}{ }^{1}$ clay and $101 \mathrm{gkg}^{-}{ }_{-}$silt, moderately acidic with a total nitrogen content of $5.30 \mathrm{gkg}^{-}{ }^{-}$. Available phosphorous was $30.20 \mathrm{mgkg}_{-}{ }^{1}$ and exchangeable potassium was $0.09 \mathrm{cmolkg}^{-}{ }^{1}$. Contents of $\mathrm{Ca}, \mathrm{Na}$ and $\mathrm{Mg}$ were $0.85 \mathrm{cmolkg}^{-}{ }^{1}, 2.02 \mathrm{cmolkg}_{-}{ }^{1}$ and $1.40 \mathrm{cmolkg-}{ }^{1}$ respectively. Cation exchangeable capacity was $13.10 \mathrm{cmolkg-}^{1}$ and exchangeable acidity was $1.07 \mathrm{cmolkg-}^{1}$ (Table 1).

\subsection{Poultry manure analysis}

The poultry manure had a pH of 7.8 , total nitrogen content of $31.9 \mathrm{gkg}-{ }^{1}$, available $\mathrm{P}$ was $0.55 \mathrm{mgkg}_{-}{ }^{1}$ and exchangeable $\mathrm{K}$ of $0.10 \mathrm{cmolkg}^{-}{ }^{1}$. Contents of $\mathrm{Ca}, \mathrm{Na}$ and $\mathrm{Mg}$ were $2.44 \mathrm{cmolkg}^{-}{ }^{1}, 0.03 \mathrm{cmolkg}^{-}{ }^{1}$ and $0.48 \mathrm{cmolkg}^{-1}$ respectively (Table 1 ). 


\subsection{Vegetative traits}

Plant height, number of leaves and stem girth of okra as affected by different fertilizer treatments are presented in (Table 2). The maximum plant height of $15.17 \mathrm{~cm}$ was recorded on $500 \mathrm{kgha}^{-}{ }^{1}$ NPK and the control with the least. There were significant differences between 500kgha- ${ }^{1}$ NPK, $400 \mathrm{kgha}^{-}{ }^{1}$ NPK and the control. The treatment $500 \mathrm{kgha}^{-1}$ NPK produced the highest number of leaves and the control with the least. There were significant differences between 500kgha- ${ }^{-1}$ NPK, 400kgha- ${ }^{-1}$ NPK and control $(\mathrm{P}>0.05)$. The maximum stem girth of $2.67 \mathrm{~cm}$ was recorded on $10 \mathrm{tha}^{-1} \mathrm{PM}$, while the control had the least. There were significant differences between 500kgha- ${ }^{1}$ NPK, $400 \mathrm{kgha}^{-1}$ NPK, 300kgha- ${ }^{1}$ NPK, 5 tha- ${ }^{1}$ PM and the control.

\subsection{Reproductive parameters}

The number of fruits, fruit length, fruit girth and fruit weight affected by the treatments is show in Table 3 . The highest number of fruits recorded on 10tha $-{ }^{1} \mathrm{PM}$ and the control with the least (Table 3). There was significant differences between 10tha- ${ }^{1}$ PM, NPK treatments and the control $(\mathrm{P}>0.05)$. Longest fruits were recorded on 10tha ${ }^{1} \mathrm{PM}$, and the control with the least. There was significant differences between 10 tha $-{ }^{1}{ }^{\mathrm{PM}}$ and all other treatment excerpt 500kgha- ${ }^{1}$ NPK $(\mathrm{P}>0.05)$. Treatments had an effect on fruit girth, with the greatest fruit girth recorded on 10 tha $-{ }^{1} \mathrm{PM}$ and the control with the least (Table 3). There was significant difference between 10 tha ${ }^{1}{ }^{1} \mathrm{PM}$ and all other treatment $(\mathrm{P}>0.05)$. The maximum fruit weight was recorded on 10 tha ${ }^{1}{ }^{1} \mathrm{PM}$ and the control with the least (Table 3). There was significant differences between 10 tha $^{-1}{ }^{-} \mathrm{PM}$ and all other treatments $(\mathrm{P}>0.05)$.

\subsection{Incidence of insect pests}

A total of 8 insect species from 5 orders (Coleoptera, Diptera, Lepidoptera, Hemiptera, and Hymenoptera) and 7 families (Chrysomelidae, Meloidae, Drosophilidae, Noctuidae, Pyralidae, Vespidae) were identified on okra. They are Monolepta golding, Nisotra dilecta, Epicarta oculata, Myzus persicae, Plycodrosophita sp, Nanthodes graellsii, Chilo sp, and Labus urundiensis.

\subsection{Monolepta golding}

Treatments with 500kgha- ${ }^{-}$NPK recorded higher number of M. goldling and where significantly different from the treatments with PM (Table 4 ).

\subsection{Nisotra dilecta}

Infestation by $N$. dilecta was observed to be higher on 500kgha- ${ }^{1}$ NPK treated plots compared to all other treatments. However, there were significant differences between $500 \mathrm{kgha}^{-1}{ }^{1}$ NPK and plots treated with PM (Table 4).

\subsubsection{Epicauta oculata}

Higher numbers of $E$. oculata were observed on $500 \mathrm{kgha}^{-}{ }^{1}$ NPK compared to other treatments. There were significant difference between 500kgha- ${ }^{1}$ NPK and plots treated with PM (Table 4).

\subsubsection{Labus urundiensis}

Infestation was higher on $500 \mathrm{kgha}^{-}{ }^{1} \mathrm{NPK}$ and 10 tha $-{ }^{1} \mathrm{PM}$ with the lowest. There was a significant difference between 500kgha- ${ }^{1}$ NPK and plots treated with PM (Table 4).

\subsubsection{Myzus persicae}

Plots treated with 500kgha- ${ }^{1}$ had the higher infestation by M. persicea (Aphids) compared to other treatments. There was significant difference between 500kgha- ${ }^{1}$ NPK and plots treated with PM (Table 4).

\subsection{Effect on soil chemistry}

\section{Discussion}

Poultry manure may have released of organic compounds which reduced the acidity of the soil (Akande et al., 2005; Okwuagwu 2003). Application of PM to soils contributes to an increase in productivity and improves yield in terms of quantity and quality (Akande et al., 2010). This study shows that the addition of PM significantly increased the amount of $\mathrm{Fe}, \mathrm{Mn}$ and $\mathrm{Na}$ in the soils. The decrease in other nutrients may be as a result of uptake by the crop, leaching, immobilization by microorganisms and volatilization (Defoer et al., 2000; Niassy et al., 2010). Somani and Totawat (1996) and Okwuagwu et al. (2003) observed similar results in their works on organic amendments in alkaline soils. This result confirms the findings of Akande et al. (2010) that organic amendment could ameliorate slightly acidic tropical soils to improve crop production. 


\subsection{Influence of amendment on vegetative traits}

Application of PM and NPK fertilizer greatly enhanced the growth and development of okra compared to the untreated controls. This shows that $\mathrm{N}$ is essential for healthy growth and production of okra. Successive levels of increase in PM and NPK resulted in a corresponding increase in both vegetative and reproductive traits in okra compared to untreated control, this indicates that an increase in nitrogen promotes vigorous plant growth. This agrees with the study of John et al. (2004) who reported that PM contains essential nutrients which are associated with high photosynthetic activities that promote root and vegetable growth. Although, there were no differences between PM and NPK for the vegetative traits measured PM outperformed NPK for all the reproductive traits measured. This agrees with the work of Dauda et al. (2008). This study shows that fertilization with PM could possibly sustain okra production under green agriculture in the tropics.

\subsection{Influence of fertilizers on the incidence of insect pests}

With the increase application of NPK, there was a corresponding increase in insect pest infestation across insect species, while the reverse is the case with PM (Adilakshimi et al., 2007; Karnataka, 2008; Zehnder et al., 2007). The study confirms the findings of the proponents of organic farming who are of the view that the likelihood of pest outbreaks is reduced with organic farming practices including the establishment and maintenance of healthy soil (Merill, 1983). The ability of PM in suppressing sucking pests of okra as revealed in the study supports the finding by Karnataka (2008) who showed that the application of organic amendments significantly lowered aphid population. Surekha and Rao (2001) also showed that organic amendment was effective in bringing down population of aphids in okra. Prakash et al. (2002) also showed lower percentages of fruit borer infestation in okra when treated with organic fertilizer.

PM has a suppressing effect on the incidence of the flea beetles. Flea beetle larvae feed on okra root and the feeding activity of adults on the leaves and fruits causes' heavy defoliation of young plants resulting in stunted growth, death, reduced quality/market value of the fruits.

The low infestations by insect pests on plots treated with PM may be as a result of the slow release of nitrogen which made them less susceptible to insect pest attack. This study agrees with the findings of Phelan $e t$ al. (1996) and Stone et al. (2000) who reported that increasing soluble nitrogen levels in plants from organic manures sources can decrease their resistance to insect pest.

\section{Conclusion}

The study shows that application of PM improved the physico-chemical properties of the soil compared to NPK and the untreated control. Organic amendments can be used to provide nutrition of okra and to attain yields that are comparable both in quantity and quality with that obtained with inorganic fertilizer. Poultry manure at the rate of 10tha- ${ }^{1}$ is therefore recommended for optimum production of okra and increased market value in the humid tropics.

The study shows that amendment with PM reduced the incidence of insect pests in okra compared to NPK. PM is eco-friendly, readily available and affordable and its bulk nature enhances soil structure for continuous cropping and sustainable agriculture in the tropics.

\section{References}

[1]. E.I. Abou-Magel, , M.A. El-Bassiony and Z.F. Fawzy, Effect of organic manure with or without chemical fertilizer on growth, yield and quality of some varieties of Broccoli plants. J. of Applied Science Res., 2(10), 2006,791-798.

[2]. A. Adilakshmi, D.M. Korat and P.R. Vaishnau, Effect of organic and inorganic fertilizers on insect pests infesting okra. Karnataka J. Agric. Sci., 21(2), 2007, 287-289.

[3]. MO.. Akande, J.A. Adediran, and F.I. Oluwatoyinbo, Effects of rock phosphate amended with poultry manure and soil available phosphate. and yield of maize and cowpea, Afri. J. Biotech, 4, 2005, 444-448.

[4]. M.O. Akande, F.I. Oluwatoyinbo, E.A. Makinde, A.S. Adepoju and I.S. Adepoju, Response of okra to organic and inorganic fertilization, Nature and Science. 8(11), 2010, 261-266.

[5]. K.O. Alasiri and O.O. Ogunkeye, Effect of different levels of poultry manure in seed yield of okra. Proceedings of the $25^{\text {th }}$ Annual Conference of the Soil science Society of Nigeria, $21^{\text {st }}-25^{\text {th }}$ November, Benin, Nigeria, 1999.

[6]. AOAC, Official Methods of Analysis Association of Official Analytical Chemists $15^{\text {th }}$ edn. (Washington DC. 1990).

[7]. N.C. Brady, and R. Weil, The nature and properties of soil $12^{\text {th }}$ edition (Mac Pub. Com. New York. 625-640, 1999).

[8]. S.N. Dauda, F.A. Ajayi and E. Ndor, Growth and yield of water melon (Citrullus lanatus) as affected by poultry manure application. J. Agric. Soc. Sci., 4, 2008 121-124.

[9]. T. Defoer, A.C. Budelan and S.E. Carter, Managing soil fertility in the tropics. FAO Press Kit Amsterdam Pp 47-63. In: M.I. Okwuagwu, M.S. Alleh and I.O. Osemwota, 2003, The effects of organic and inorganic manure on soil properties and yield of okra in Nigeria. African Crop Science Conference Proceedings. 6, , 2000, 390-393.

[10]. Economic Commission of Africa. State of the environment in africa. (P.O. Box 3001, Addis Ababa, Ethopia ECA/FSSDD/10/06.,2001).

[11]. FAO. The state of food and agriculture (Food and Agriculture Organization of the United Nations. 2006).

[12]. O.O. Folorunso and S.O. Ojeniyi, Effect of sole and amended plant residence on soil content yield of okra. Dept of Crop Soil and Pest Management, Federal University of Technology Akure Nigeria Asset series 3(4), 2003, 65-53.

[13]. L.W. John, D.B. Jamer, L.T. Samuel and L.W. Warmer,. Soil fertility and fertilizers and introduction to nutrient management. (Parson Edu. India, 2004). 
[14]. Karnataka.. Effect of organic manures and inorganic fertilizers on insect pests infesting okra. J. Agric. Sci. 21(2), 2008, 287-289.

[15]. M.C. Merill, Bio-agriculture: A review of its history and philosophy, Biology Agriculture and Horticulture, 1, 1983,181- 210.

[16]. [16]S. Muhammed, N.A. Amusa, H.A. Subeni, A. Abubakar and D. Magaji, The effects of soil amendment with saw dust and rice husks on the incidence of seedling blight caused by Fusarium solani and Rhizoctonia solani and the growth of Parkia biglobosa, Moor Journal of Agricultural Research 2, 2001, 40-46.

[17]. National Research council. Okra lost crops of Africa. Vol. II Vegetables, 2006.

[18]. S. Niassy, K. Diarra, Y. Niang, S. Niang and H.R. Pfiefer, Effect of organic fertilizers on the susceptibility of tomato Lycopersicon esculentum: Solanaceace to Helicoverpa armigera Lepidoptera in the Niayes area of Senegal. Research Journal of Agriculture and Biological Sciences, 6(6), 2010,708-712.

[19]. [19]B.N. Okigbo, Cropping systems and land degradation in the tropics. Soil fertility, soil tilth and post clearing. Land degradation in the humid tropics. Proc. Inter. Soc. of Soil Sci. (commission iv and vi) organized by the SSSN $21^{\text {st }}-26^{\text {th }}$ July, Ibadan, Nigeria, 1985

[20]. [20]M.I. Okwuagwu, M.E. Alleh and I.O. Osemwota, The effect of organic and inorganic manure in soil properties in Nigeria. African Crop Science Conference Proceedings, 6, 2003, 390-393

[21]. [21]P.L. Phelan, K.H. Norris and J.F. Manson, Evidence for plant mineral balance mediating insect-plant interaction. Environmental Entomology, 25, 1996, 1329-1336.

[22]. [22]Y.S. Prakash, P.B.S. Bhadoria and R. Amitava, Relative efficiency of organic manure in improving resistance and pest tolerance of Okra, Ann. Agr Res. 23, 2002, 525-531.

[23]. [23]A.R. Sharma and B.N. Mittra, Effect of different rates of application of organic, Journal of Agric Science 117, 1991, 33-318

[24]. [24]L.L. Somani and I.L. Totawat, Soil conditions and amendments (Agrotech Pub. Academy. Udesipur. $1^{\text {st }}$ edition 1996).

[25]. [25]A.G. Stone, S.J. Schencrell and H.M. Parby, Organic matter, cover cropping and other cultural practices 2000.

[26]. [26]J. Surekha and P.A. Rao, Management of aphids on bhendi with organic sources of NPK and certain insecticides. Andhra Agricultural Journal, 48, 2001, 56-60.

[27]. [27] H.D. Tindall,. Vegetables in the tropical (Macmillan Press Ltd. 1992)

[28]. [28] G. Zehnder, G.M. Gurr, S. Kühne, M.R. Wade, S.D. Wratten and E. Wyss, Arthropod management in organic crops. Annual Review of Entomology, 52, 2007, 57-80.

Table 1: Physiochemical properties of the soil before and after treatment and poultry manure (PM).

\begin{tabular}{|c|c|c|c|c|c|c|c|c|}
\hline \multirow[t]{2}{*}{ Parameters } & \multirow[t]{2}{*}{ PM } & \multirow{2}{*}{$\begin{array}{l}\text { Before } \\
\text { experimen } \\
t\end{array}$} & \multicolumn{6}{|c|}{ After experiment } \\
\hline & & & $\begin{array}{l}500 \mathrm{kgha}^{-1} \\
\mathrm{NPK}\end{array}$ & $\begin{array}{l}400 \mathrm{kgha}^{2} \\
\mathrm{MPK}\end{array}$ & $\begin{array}{l}300 \mathrm{kgha}{ }^{-1} \\
\text { NPK }\end{array}$ & $\begin{array}{l}\text { 10thas: } \\
\text { PMI }\end{array}$ & $\begin{array}{l}7.5 \text { tha }^{-1} \\
\text { PMM }\end{array}$ & $\begin{array}{l}\text { Sthat } \\
\text { PM }\end{array}$ \\
\hline $\mathrm{pH}$ & 7.80 & 4.80 & 5.70 & 5.00 & 5.00 & 5.10 & 5.40 & 5.50 \\
\hline E. cation (mm-) & $0.50^{-}$ & 7.87 & $4.00^{-}$ & $6.00^{-1}$ & $4.00^{-}$ & 2.00 & 2.00 & 3.00 \\
\hline 0. carbon (gkg-s) & 274.50 & 22.00 & 22.00 & $18.70^{-}$ & 22.30 & 21.20 & 21.80 & 25.50 \\
\hline Total N(gkg-5) & 31.90 & 5.30 & 5.30 & $4.50^{-}$ & $5.40^{-}$ & 5.10 & 5.30 & $6.20^{-}$ \\
\hline Av. $\mathrm{P}(\mathrm{mgkg})$ & $0.55^{-}$ & 30.20 & 15.64 & 15.98 & 16.8 & 13.99 & 24.21 & 17.34 \\
\hline $\mathrm{Ca}(\mathrm{cmolkg}-)^{-}$ & 2.44 & 8.47 & 0.38 & 0.26 & 0.28 & 0.39 & 0.94 & $0 . \overline{15}$ \\
\hline $\mathrm{Mg}(\mathrm{cmolkg}-)^{-}$ & 0.48 & 1.40 & 0.95 & 1.18 & 1.18 & 0.99 & $1 . \overline{4}$ & 0.98 \\
\hline $\mathrm{K}(\mathrm{cmolkg}-\mathrm{s})$ & 0.10 & 2.02 & 0.25 & 0.23 & 0.22 & 0.23 & 0.34 & 0.69 \\
\hline $\mathrm{Na}(\mathrm{cmolkg}-)^{-}$ & 0.03 & $0 . \overline{0} 9^{-}$ & 1.02 & $\overline{2} \cdot \overline{1} \overline{1}$ & 1.84 & $0.82^{-}$ & 1.63 & 1.74 \\
\hline Ex. Acidity (cmolkg- $)^{--}$ & - & $1.07^{-}$ & $-\overline{-6}-40^{--}$ & $0.40^{--}$ & $-\overline{-1}-40^{--}$ & $0.80^{-}$ & $0.60^{-}$ & $0.60^{-}$ \\
\hline C.E.C.(cmolg- & $\because$ & 13.10 & $3.00^{-1}$ & 4.18 & 3.92 & 3.23 & $4.95^{-1}$ & 4.16 \\
\hline Base Sat. (\%) & $\because$ & 91.75 & 86.67 & $90.43^{-}$ & 89.8 & 75.23 & 87.88 & 85.58 \\
\hline $\mathrm{No}$ (mgkg) & 0.01 & 19.40 & 64.4 & $87.60^{-}$ & 51.1 & $63.6^{-}$ & 56.7 & 59.39 \\
\hline $\mathrm{F}=(\mathrm{mgkg})$ & 0.013 & 29.70 & $133^{-}$ & $14 \overline{2}$ & 111 & 119 & 109 & 113 \\
\hline $\mathrm{cu}(\mathrm{mglg})$ & $0.003^{-}$ & 2.07 & 3.02 & $3.33^{-}$ & 2.91 & 2.31 & $2.37^{-}$ & 3.20 \\
\hline $\mathrm{Zn}(\mathrm{mgkg})$ & $0.002^{-}$ & 6.99 & 2.76 & 2.98 & 2.32 & $2.85^{-}$ & $3.72^{-}$ & 2.49 \\
\hline
\end{tabular}

Table 2: $\quad$ Vegetative traits of okra

\begin{tabular}{|c|c|c|c|}
\hline Treatments & Plant height_(cm) & Number of leaves & Stem girth $(\mathrm{cm})$ \\
\hline $500 \mathrm{kgha}^{-}{ }^{1} \mathrm{NPK}$ & $15.17^{\mathrm{a}}$ & $8.77^{\mathrm{a}}$ & $2.60^{\mathrm{a}}$ \\
\hline 400kgha- ${ }^{1}$ NPK & $12.17^{\mathrm{b}}$ & $7.02^{\mathrm{c}}$ & $2.46^{\mathrm{b}}$ \\
\hline 300 kgha- $^{1}$ NPK & $14.60^{\mathrm{a}}$ & $8.19^{\mathrm{ab}}$ & $2.34^{\mathrm{cd}}$ \\
\hline 10tha- ${ }^{1} \mathrm{PM}$ & $15.04^{\mathrm{a}}$ & $8.15^{\mathrm{ab}}$ & $2.67^{\mathrm{a}}$ \\
\hline 7.5 tha- ${ }^{1} \mathrm{PM}$ & $13.84^{\mathrm{ab}}$ & $7.50^{\mathrm{bc}}$ & $2.34^{\mathrm{bc}}$ \\
\hline 5tha- ${ }^{1} \mathrm{PM}$ & $14.56^{\mathrm{a}}$ & $8.28^{\mathrm{a}}$ & $2.27^{\mathrm{d}}$ \\
\hline Control & $9.01^{\mathrm{c}}$ & $6.14^{\mathrm{d}}$ & $1.74^{\mathrm{e}}$ \\
\hline LSD & 1.75 & 0.69 & 0.09 \\
\hline
\end{tabular}


Effect Of Organic And Inorganic Fertilizers On Okra (Abelmoschus esculentus L. Moench)...

Table 3: Reproductive traits

\begin{tabular}{|c|c|c|c|c|}
\hline Treatments & $\begin{array}{l}\text { Fruit } \\
\text { number }\end{array}$ & $\begin{array}{l}\text { Fruit length } \\
(\mathrm{cm})\end{array}$ & $\begin{array}{l}\text { Fruit girth } \\
(\mathrm{cm})\end{array}$ & $\begin{array}{l}\text { Fruit weight } \\
\text { (g) }\end{array}$ \\
\hline 500kgha- ${ }^{1}$ NPK & $6.33^{\mathrm{b}}$ & $10.33^{\mathrm{ab}}$ & $3.00^{\mathrm{b}}$ & $15.00^{\mathrm{bcd}}$ \\
\hline 400kgha- ${ }^{1}$ NPK & $5.67^{\mathrm{b}}$ & $8.33^{\mathrm{bc}}$ & $1.67^{\mathrm{bc}}$ & $11.67^{\mathrm{d}}$ \\
\hline 300 kgha $^{-1}$ NPK & $5.33^{\mathrm{b}}$ & $8.33^{\mathrm{bc}}$ & $2.33^{\mathrm{bc}}$ & $13.00^{\mathrm{cd}}$ \\
\hline 10 tha- ${ }^{1} \mathrm{PM}$ & $9.67^{\mathrm{a}}$ & $13.33^{\mathrm{a}}$ & $4.67^{\mathrm{a}}$ & $23.67^{\mathrm{a}}$ \\
\hline 7.5 tha- ${ }^{1} \mathrm{PM}$ & $3.67^{\mathrm{c}}$ & $5.67^{\mathrm{cd}}$ & $1.67^{\mathrm{bc}}$ & $18.33^{\mathrm{bcd}}$ \\
\hline 5 tha- ${ }^{1} \mathrm{PM}$ & $5.33^{\mathrm{b}}$ & $8.33^{\text {bc }}$ & $1.67^{\mathrm{bc}}$ & $16.00^{\text {bcd }}$ \\
\hline Control & $2.33^{\mathrm{c}}$ & $4.00^{\mathrm{d}}$ & $1.33^{\mathrm{c}}$ & $6.00^{\mathrm{e}}$ \\
\hline LSD & 1.67 & 3.17 & 1.48 & 3.74 \\
\hline
\end{tabular}

Table 4: Insect pests on okra

\begin{tabular}{|c|c|c|c|c|c|}
\hline Treatments & M. golding & N. dilecta & E. oculata & L. urundiensis & M. persicea \\
\hline $500 \mathrm{kgha}^{-1} \mathrm{NPK}$ & $21.75^{\mathrm{a}}$ & $14.00^{\mathrm{a}}$ & $7.00^{\mathrm{a}}$ & $11.00^{\mathrm{a}}$ & $10.25^{\mathrm{a}}$ \\
\hline 400kgha- ${ }^{1}$ NPK & $16.25^{\mathrm{ab}}$ & $11.25^{\mathrm{ab}}$ & $5.25^{\mathrm{b}}$ & $7.25^{\mathrm{b}}$ & $8.50^{\mathrm{bc}}$ \\
\hline $300 \mathrm{kgha}^{1}{ }^{1} \mathrm{NPK}$ & $12.25^{\mathrm{bc}}$ & $7.50^{\mathrm{cd}}$ & $3.75^{\mathrm{cd}}$ & $5.50^{\mathrm{bcd}}$ & $6.50^{\mathrm{d}}$ \\
\hline 10tha- ${ }^{1} \mathrm{PM}$ & $7.25^{\mathrm{c}}$ & $4.00^{\mathrm{e}}$ & $1.25^{\mathrm{e}}$ & $3.00^{\mathrm{d}}$ & $3.75^{\mathrm{e}}$ \\
\hline 7.5 tha- ${ }^{1} \mathrm{PM}$ & $8.00^{\mathrm{bc}}$ & $4.50^{\mathrm{de}}$ & $1.25^{\mathrm{e}}$ & $4.00^{\mathrm{cd}}$ & $4.50^{\mathrm{e}}$ \\
\hline 5tha- ${ }^{1} \mathrm{PM}$ & $11.00^{\mathrm{bc}}$ & $7.00^{\text {cde }}$ & $2.75^{\mathrm{d}}$ & $6.25^{\mathrm{bc}}$ & $7.50^{\mathrm{cd}}$ \\
\hline Control & $14.50^{\mathrm{abc}}$ & $9.50^{\mathrm{bc}}$ & $4.50^{\mathrm{bc}}$ & $7.75^{\mathrm{b}}$ & $9.00^{\mathrm{ab}}$ \\
\hline LSD & 8.59 & 3.42 & 1.46 & 2.08 & 1.49 \\
\hline
\end{tabular}

